\title{
EQUILIBRIUM AND KINETIC STUDIES OF ANIONIC SURFACTANT REMOVAL BY ADSORPTION AND PHOTOCATALYTIC DEGRADATION USING HYDROTALCITE-LIKE COMPOUNDS AND THEIR CALCINED PRODUCTS
}

\author{
Farid AOUDJIT, ${ }^{\mathrm{a}, *}$ Ouiza CHERIFI ${ }^{\mathrm{a}, \mathrm{b}}$ and Djamilla HALLICHE ${ }^{\mathrm{b}}$ \\ ${ }^{a}$ Laboratory of Petrochemical Synthesis, Faculty of Hydrocarbons and Chemistry, University of M'Hamed Bougara, \\ Boumerdes 35000, Algeria \\ ${ }^{\mathrm{b}}$ Laboratory of Natural Gas Chemistry, Faculty of Chemistry, University of Sciences and Technology,Houari Boumediene, \\ BP 32 El-Allia, Bab Ezzouar, Algiers 16 111, Algeria
}

Due to the abundant use of anionic surfactants in our life and their disposal in the environment, the removal of surfactants from waste water becomes necessary.

The present study focused to the synthesis and application of layered double hydroxides and their derived oxides to remove the anionic surfactant, sodium dodecyl sulphate (SDS), from aqueous solution by adsorption and photocatalytic degradation under UV irradiation. The influencing of $\mathrm{Zn}^{2+} / \mathrm{Al}^{3+}$ molar ratio and initial SDS concentration on the adsorption and photocatalytic degradation of SDS are studied and optimized. The obtained adsorption data were correlated with Langmuir and Freundlich isotherms models. Equilibrium studies indicated that the SDS removal obeyed Langmuir type of adsorption. Kinetic data were better described by pseudo-second-order model. The photocatalytic degradation of SDS has been found to fit the firstorder kinetics according to the Langmuir-Hinshelwood model.

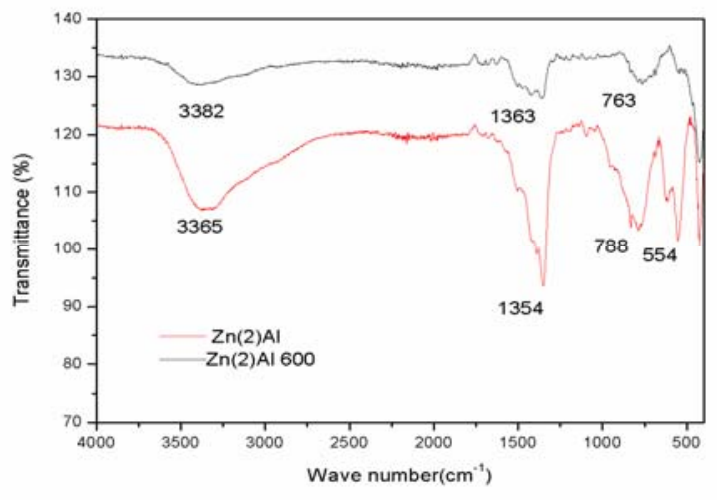

\section{INTRODUCTION}

Anionic surfactants are present in a large variety of products like soaps, detergents, and personal care products and are widely used in many industrial applications. After use, residual surfactants are discharged into sewage systems. It is reported that in domestic sewage, the anionic surfactants concentration may vary from 1 to $18 \mathrm{mg} / \mathrm{L}$ and in industrial waste water the concentration reaches up to $300 \mathrm{mg} / \mathrm{L} .^{1,2}$ Many environmental and public health regulatory authorities have fixed stringent limits for the anionic surfactants standard of $0.5 \mathrm{mg} / \mathrm{L}$ for drinking water and $1.0 \mathrm{mg} / \mathrm{L}$ for other purposes. ${ }^{3}$

Many processes have been proposed for the surfactants removal, such as coagulation, ${ }^{4,5}$ photocatalytic degradation ${ }^{6,7}$ and adsorption. ${ }^{8,9}$ Among the currently used techniques, adsorption has received considerable attention due to its high removal efficiency and low-cost. Layered double hydroxides $(\mathrm{LDH})$ are receiving more and more attention in recent years because it is environmentfriendly and cost-effective. Layered double hydroxides

${ }^{*}$ Corresponding author: faoudjit $@$ yahoo.fr 
(LDH), also known as hydrotalcite-like compounds, are a class of synthetic anionic layered clays containing brucite-like layers and positively-charged sheets. They can be represented by the general formula: $\left[\mathrm{M}_{1-x}^{2+} M_{x}^{3+}(\mathrm{OH})_{2}\right]^{x+} \cdot\left(A_{x / n}^{n-}\right) \cdot m \mathrm{H}_{2} \mathrm{O}$; where $\mathrm{M}^{2+}$ and $M^{3+}$ are the divalent and trivalent cations, respectively, $A^{n-}$ represents the interlayer anion with a charge (n-) and $x$ is equal to the ratio of $M^{3+} /\left(M^{2+}+\right.$ $M^{3+}$ ) with a value varying in the range of $0.17-0.50$. LDH materials present properties like layered structure, high porosity, high surface area, and interlayer anion mobility.

The purpose of this study is to investigate the adsorption and photocatalytic degradation under UV irradiation of SDS surfactant on the uncalcined and calcined LDH materials, synthesized with different cationic ratios $(\mathrm{Zn} / \mathrm{Al})$. Many parameters such $\mathrm{Zn}^{2+} / \mathrm{Al}^{3+}$ molar ratio, initial SDS concentration are investigated. Isotherms and kinetics analysis are detailed in this study.

\section{EXPERIMENTAL}

\section{Materials preparation}

All chemicals were analytical grade and used as received without further purification.

The materials types LDH were prepared by the coprecipitation method at constant $\mathrm{pH}$ (11) with cationic ratio $\left(\mathrm{Zn}^{2+} / \mathrm{Al}^{3+}\right)$ of 2,3 and 4 . In this method, $100 \mathrm{~mL}$ of solution containing a fixed amount of $\mathrm{Zn}\left(\mathrm{NO}_{3}\right)_{2} \cdot 6 \mathrm{H}_{2} \mathrm{O}$ (0.14 moles) and $\mathrm{Al}\left(\mathrm{NO}_{3}\right)_{3} \cdot 9 \mathrm{H}_{2} \mathrm{O}(0.066,0.045$ and 0.034 moles $)$ were added dropwise, to $100 \mathrm{~mL}$ of an alkaline solution containing $\mathrm{NaOH}(0.3$ moles $)$ and $\mathrm{Na}_{2} \mathrm{CO}_{3}$ (0.094 moles) under vigorous stirring. The resulting slurry was hydrothermally treated; it was placed for $8 \mathrm{~h}$ on oil bath at $60{ }^{\circ} \mathrm{C}$ under magnetic stirring and reflux. The final products were recuperated by filtration, washed several times with distilled water until reaching $\mathrm{pH} \approx 7$ and the precipitates obtained were dried at $80{ }^{\circ} \mathrm{C}$ overnight.

The calcined LDH was obtained by calcination of $\mathrm{LDH}$ samples in a muffle furnace at $600{ }^{\circ} \mathrm{C}$ for $4 \mathrm{~h}$, with heating in increments of $5{ }^{\circ} \mathrm{C} / \mathrm{min}$.

The dried samples were denoted as $\mathrm{Zn}(\mathrm{r}) \mathrm{Al}$ and calcined samples denoted as $\mathrm{Zn}(\mathrm{r}) \mathrm{Al} 600$, where $r$ stands for the cationic ratio (2, 3 and 4$)$ and 600 is the calcination temperature.

\section{Materials characterization}

The crystalline phases of samples were identified by X-ray powder diffraction (XRD) using Panalytical X'Pert PRO MPD diffractometer with filtered $\mathrm{Cu} \mathrm{K} \alpha$ radiation in $2 \theta$ range from 5 to $70^{\circ}$. The texture of samples was analysed by low temperature nitrogen adsorption at $-196^{\circ} \mathrm{C}$ (Micromiritics ASAP 2000) using Quantachrome Autosorb 1-MPautomated gas adsorption system. Fourier transform infrared (FTIR) spectra were recorded on a Bruker ALPHA spectrophotometer, at a resolution of $2 \mathrm{~cm}^{-1}$ and averaging over 20 scans, in the range $400 \mathrm{~cm}^{-1}-4000 \mathrm{~cm}^{-1}$. The morphology of the samples was investigated using scanning electron microscopy (Quanta 250) with an accelerating voltage of $20 \mathrm{kV}$, combined with energy dispersive X-ray spectroscopy (Système EDX Bruker EDS Quantax 200) for the determination of materials composition.

\section{Adsorption studies}

The adsorption study was carried out using the batch method. It was performed by introducing a given amount of adsorbent into $100 \mathrm{~mL}$ Erlenmeyer flasks containing $50 \mathrm{~mL}$ of an aqueous SDS solution with desired concentration. The mixture was shaken for the desired period at $25^{\circ} \mathrm{C}$ using a shaking rotating incubator (KS 4000, IKA, Germany) at 200 $\mathrm{rpm}$. After shaking period, the mixture was then filtered, and the filtrate was analyzed by UV-vis spectrophotometer at 648 $\mathrm{nm}$ to determine the residual concentration of SDS using a simplified spectrophotometric method developed by Jurado. ${ }^{10}$ Adsorption experiments were conducted by varying, adsorbent dose, initial SDS concentration, contact time and temperature.

The adsorption capacity $q_{t}(\mathrm{mg} / \mathrm{g})$ is calculated using the following equation:

$$
q_{t}=\frac{\left(C_{0}-C_{t}\right)}{m} \times V
$$

where $C_{0}$ and $C_{t}$ are the initial concentration and concentration at time $(t)$ of SDS, $V$ is the volume of SDS solution $(L)$ and $(m)$ is the mass of adsorbent $(g)$.

\section{Photocatalytic degradation studies}

The photocatalytic degradation experiments were carried out using a $500 \mathrm{~mL}$ double-glass cylindrical reactor. The temperature in this reactor is controlled by the constant circulation of water. The SDS solution with photocatalyst were magnetically stirred using a magnetic stirrer. The radiation source used was a 100 watt UV lamp (type BlackRay B100AP UV $230 \mathrm{~V}-50 \mathrm{~Hz}$ ), with maximum emission at $365 \mathrm{~nm}$. The desired dose of photocatalyst was introduced into the reactor vessel containing $100 \mathrm{~mL}$ of SDS solution with desired concentration. Prior to irradiation, the solution was magnetically stirred in the dark for $60 \mathrm{~min}$ to allow the adsorption of SDS to the photocatalyst. $5 \mathrm{~mL}$ of the solution was withdrawn from the reactor vessel periodically and filtered. Then the filtrate was analyzed by UV-vis spectrophotometry at $648 \mathrm{~nm}$ to determine the residual concentration of SDS.

The SDS removal efficiency was calculated as follows:

$$
R(\%)=\frac{\left(C_{0}-C_{t}\right)}{C_{0}} \times 100
$$

where $C_{0}$ and $C_{t}$ are the initial concentration and concentration at time $(t)$ of SDS.

\section{RESULTS AND DISCUSSION}

\section{Characterization}

\section{$X$-ray diffraction $(X R D)$}

The XRD patterns of $\mathrm{Zn}(2) \mathrm{Al}$ and $\mathrm{Zn}(2) \mathrm{Al} 600$ are shown in Fig. 1. It could be seen clearly from this figure that the XRD patterns of $\mathrm{Zn}(2) \mathrm{Al}$ exhibit a 
series of characteristic reflections of well-crystallized hydrotalcite-like structure, which are sharp and symmetric at low $2 \theta$ angle (planes of 003, 006 and 012), but broad and asymmetric at high $2 \theta$ angle (planes of 015,018 and 110). ${ }^{11,12}$ As seen from the XRD patterns of $\mathrm{Zn}(2) \mathrm{Al} 600$ (calcined sample at 600 $\left.{ }^{\circ} \mathrm{C}\right)$, the (003) and (006) reflections observed in the $\mathrm{Zn}(2) \mathrm{Al}$ practically disappeared indicating that the hydrotalcite structure is destroyed and there is disordering in the stacking of the layers and only $\mathrm{ZnO}$ peaks are observed.

Lattice parameters of the $\mathrm{Zn}(2) \mathrm{Al}$ sample $\left(d_{003}\right.$, $d_{110}, c$ and $a$ ) are shown in Table 1 .

The cell parameters were calculated as $a=2 \times d_{110}$ and $c=3 \times d_{003}$, respectively. ${ }^{13}$

The unit cell parameter $(a)$ is the average distance between two metal ions in the brucite-like layers and $(c)$ is three times the distance from the center of one layer to the next, and is directly related to the layer charge density and size as well as to the interlayer anionic electrostatic interaction.

\section{Fourier transform infrared spectroscopy analysis (FTIR)}

The Fig. 2 shows the FTIR spectra of Zn(2)Al and $\mathrm{Zn}(2) \mathrm{A} 1600$ samples. A strong broad absorbance band appears at around $3365 \mathrm{~cm}^{-1}$, which is attributed to the hydroxyl group stretching vibration in the brucite-like layers and the interlayer water molecules. ${ }^{14,15}$ The band observed at about $1354 \mathrm{~cm}^{-1}$ is assigned to the asymmetric stretching mode of the carbonate anions. ${ }^{16,17}$ Finally, the bands ranging from 400 to $800 \mathrm{~cm}^{-1}$ can be attributed to the characteristic stretching bands of $\mathrm{M}-\mathrm{O}$ and O-M-O vibration. ${ }^{18-20}$ As seen from the FTIR spectrum of the calcined sample $\mathrm{Zn}(2) \mathrm{Al600}$ all the absorption bands are weakened, compared to the as synthesized $\mathrm{Zn}(2) \mathrm{Al}$, the peak intensity of $\mathrm{CO}_{3}{ }^{2-}$ ions at $1363 \mathrm{~cm}^{-1}$ become relatively weaker, indicating that more $\mathrm{CO}_{3}{ }^{2-}$ ions in the interlayer are removed.

\section{Brunauer-Emmer-Teller analysis (BET)}

The structure parameters of the studied samples such as the BET surface area, average pore-size and pore volume are listed in Table 2.

The samples exhibit a strong characteristic of mesoporous materials ${ }^{21,22}$ and this result is further confirmed by the well-developed mesopores with diameters of 6.475 and $4.571 \mathrm{~nm}(2<\mathrm{d}<50 \mathrm{~nm})$ given in Table 2.

Table 1

Cell parameters and crystallite sizes of $\mathrm{Zn}(2) \mathrm{Al}$

\begin{tabular}{l|ccccc}
\hline \multirow{2}{*}{ Adsorbent } & \multicolumn{2}{|c}{ Unit cell parameter $(\mathrm{nm})$} & & \multicolumn{2}{c}{ Crystal size $(\mathrm{nm})$} \\
\cline { 2 - 3 } \cline { 5 - 6 } & $\mathrm{c}$ & $\mathrm{a}$ & & $\mathrm{d}_{003}$ & $\mathrm{~d}_{110}$ \\
\hline $\mathrm{Zn}(2) \mathrm{Al}$ & 2.3064 & 0.3081 & & 0.7688 & 0.1540 \\
\hline
\end{tabular}

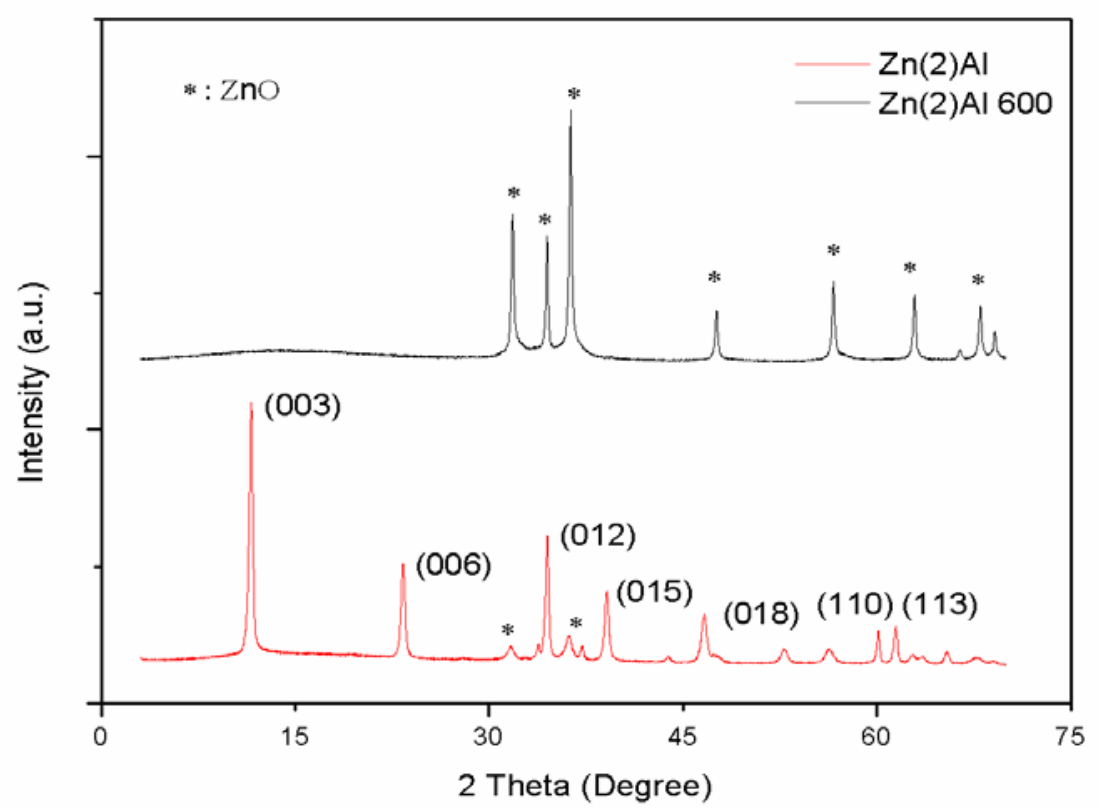

Fig. 1 - XRD patterns of $\mathrm{Zn}(2) \mathrm{Al}$ and $\mathrm{Zn}(2) \mathrm{Al} 600$. 


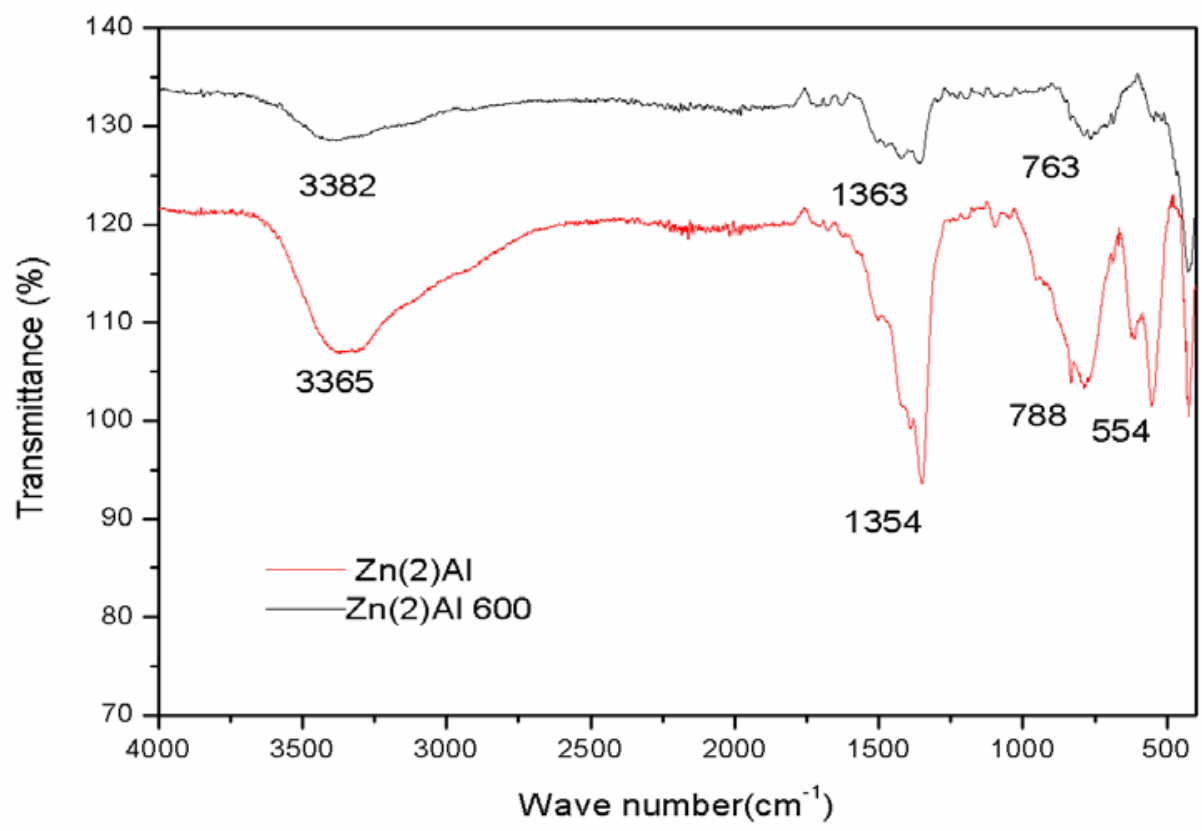

Fig. 2 - FTIR spectra of $\mathrm{Zn}(2) \mathrm{Al}$ and $\mathrm{Zn}(2) \mathrm{Al} 600$.

Table 2

Summary of BET analysis results of $\mathrm{Zn}(2) \mathrm{Al}$ and $\mathrm{Zn}(2) \mathrm{A} 1600$

\begin{tabular}{l|ccc}
\hline \multicolumn{1}{c|}{ Adsorbent } & $\begin{array}{c}\text { BET surface area } \\
\left(\mathrm{m}^{2} / \mathrm{g}\right)\end{array}$ & $\begin{array}{c}\text { Pore volume } \\
\left(\mathrm{cm}^{3} / \mathrm{g}\right)\end{array}$ & $\begin{array}{c}\text { Average pore diameter } \\
(\mathrm{nm})\end{array}$ \\
\hline $\mathrm{Zn}(2) \mathrm{Al}$ & 33.21 & 0.0537 & 6.4754 \\
$\mathrm{Zn}(2) \mathrm{A} 1600$ & 72.08 & 0.0823 & 4.571 \\
\hline
\end{tabular}

The BET surface area of the calcined sample ( $\mathrm{Zn}(2) \mathrm{A} 1600)$ is $72.08 \mathrm{~m}^{2} / \mathrm{g}$ which is higher than that of the uncalcined sample $\left(33.21 \mathrm{~m}^{2} / \mathrm{g}\right)$. The pore volume values of the calcined LDH are also increasing. When the synthesized solids are calcined, the lamellar structure collapses, which produced cavities or crates resulting in larger surface areas.

\section{Energy dispersive X-ray spectroscopy}

The final composition of the synthesized samples was determined by high energy dispersive $\mathrm{X}$-ray spectrometer. The results obtained are presented in Table 3.

The $x\left(\mathrm{M}^{3+} / \mathrm{M}^{2+}+\mathrm{M}^{3+}\right)$ value obtained for $\mathrm{Zn}(2) \mathrm{Al}$ was 0.35 the obtained value is between
0.2 and 0.35 , which is considered as the optimum value for the preparation of pure LDH structures. ${ }^{13}$

\section{Adsorption studies}

\section{Effect of $Z n / A l$ molar ratio and calcination on SDS adsorption}

The effect of varying $\mathrm{Zn} / \mathrm{Al}$ molar ratio of $\mathrm{LDH}$ on the SDS removal was investigated with three different ratios of 2, 3 and 4. Fig. 3 shows that the removal capacity decreased with increasing $\mathrm{Zn} / \mathrm{Al}$ molar ratio. This could be due to the fact that $\mathrm{Zn}(2) \mathrm{Al}$ contains a higher amount of $\mathrm{Al}^{3+}$ and the net positive charge on the hydroxide layer was higher than $\mathrm{Zn}(3) \mathrm{Al}$ and $\mathrm{Zn}(4) \mathrm{Al}$.

Table 3

Chemical formula and chemical composition Samples based on the EDX results

\begin{tabular}{l|ccccccc}
\hline \multicolumn{1}{c|}{ Adsorbent } & $\begin{array}{c}\mathrm{Zn} \\
(\mathrm{wt} \%)\end{array}$ & $\begin{array}{c}\mathrm{Al} \\
(\mathrm{wt} \%)\end{array}$ & $\mathrm{Zn}($ Atom\%) & $\begin{array}{c}\mathrm{Al} \\
(\mathrm{Atom} \%)\end{array}$ & $\begin{array}{c}\mathrm{Zn}^{2+} / \mathrm{Al}^{3+} \\
\text { molar ratio }\end{array}$ & $\mathrm{X}$ & Chemical formula \\
\hline $\mathrm{Zn}(2) \mathrm{Al}$ & 54.17 & 13.86 & 24.45 & 15.15 & 1.61 & 0.35 & $\mathrm{Zn}_{0.65} \mathrm{Al}_{0.35}$ \\
$\mathrm{Zn}(2) \mathrm{Al} 600$ & 61.56 & 11.60 & 30.88 & 14.09 & - & - & - \\
\hline
\end{tabular}

$\mathrm{x}=\mathrm{Al}^{3+} /\left(\mathrm{Zn}^{2+}+\mathrm{Al}^{3+}\right)$ 
Fig. 3 also shows that adsorption of SDS on calcined LDH was appreciably higher than the LDH. The increase in adsorption capacity of calcined LDH may be due to two main reasons: (i) the increase of specific surface area by calcination treatment and simultaneously the release of intercalated anions (mainly $\mathrm{CO}_{3}{ }^{2}$ ) from the precursor interlayer space, which produces more active sites for SDS adsorption; and (ii) the increase of positive surface charge by calcination treatment, which contributes to an electric charge effect between the oxides and SDS molecules which are negatively charged in aqueous solution. ${ }^{23,24}$

\section{Effect of contact time and initial SDS concentration}

The Fig. 4 shows that the equilibrium adsorption increases with increasing contact time at all initial SDS concentrations and equilibrium adsorption state was reached after $120 \mathrm{~min}$. This short equilibrium time often reflects the physical adsorption. ${ }^{25}$

The adsorption capacity of SDS increases with increasing initial SDS concentration. The increase in adsorption capacity with increasing initial concentration of SDS can be explained by the existence of a higher concentration gradient, which increases the diffuse contribution of the mass transfer process. The higher concentration of adsorbate in the solution increases the electrostatic repulsion between molecules in the medium, increasing the diffuse resistance to mass transfer within the solution.

\section{Kinetic studies}

Pseudo first- order and pseudo-second-order kinetic models were applied to the data at different initial concentrations of SDS. The results of the kinetics parameters of SDS adsorption on $\mathrm{Zn}(2) \mathrm{Al}$ and $\mathrm{Zn}(2) \mathrm{Al} 600$ are presented in Table 4.

According to the Tab. 4 the $R^{2}$ values of the pseudo-second order were observed to be close to 1 with all initial concentrations which were higher than those of pseudo-first-order.

Moreover, calculated, $q_{e}$ cal values from pseudo-second-order fitting model are very close to the experimental $q_{e}$ values (Table 4). From these observations, it can be concluded that the pseudosecond-order kinetic model is more applicable for describing the adsorption process of SDS on the prepared $\mathrm{Zn}(2) \mathrm{Al}$ and $\mathrm{Zn}(2) \mathrm{A} 1600$. It is suggested that the SDS adsorption was controlled by chemisorption involving the valence forces through sharing or exchange of electrons between adsorbent and adsorbate.

\section{Adsorption Isotherms}

In the present study the Langmuir and Freundlich isotherms have been chosen to explain the sorption mechanisms and the surface properties of the adsorbents.

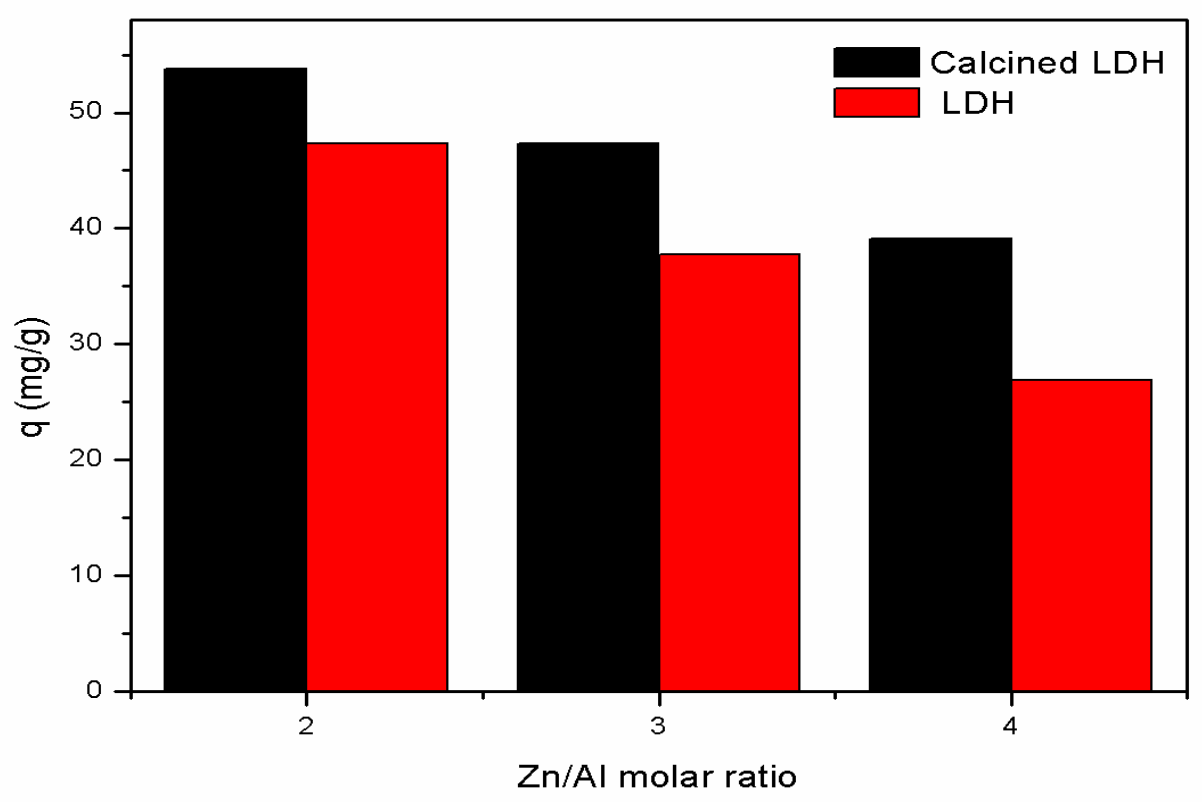

Fig. 3 - Effect of $(\mathrm{Zn} / \mathrm{Al})$ molar ratio and calcination on SDS adsorption $\left(\mathrm{C}_{0}=100 \mathrm{mg} / \mathrm{L}\right.$, adsorbent dose $=1 \mathrm{~g} / \mathrm{L}, \mathrm{pH}=$ neutral, $\mathrm{T}=25^{\circ} \mathrm{C}$, contact time $=160 \mathrm{~min}$, stirring speed $=200 \mathrm{rpm}$ ). 


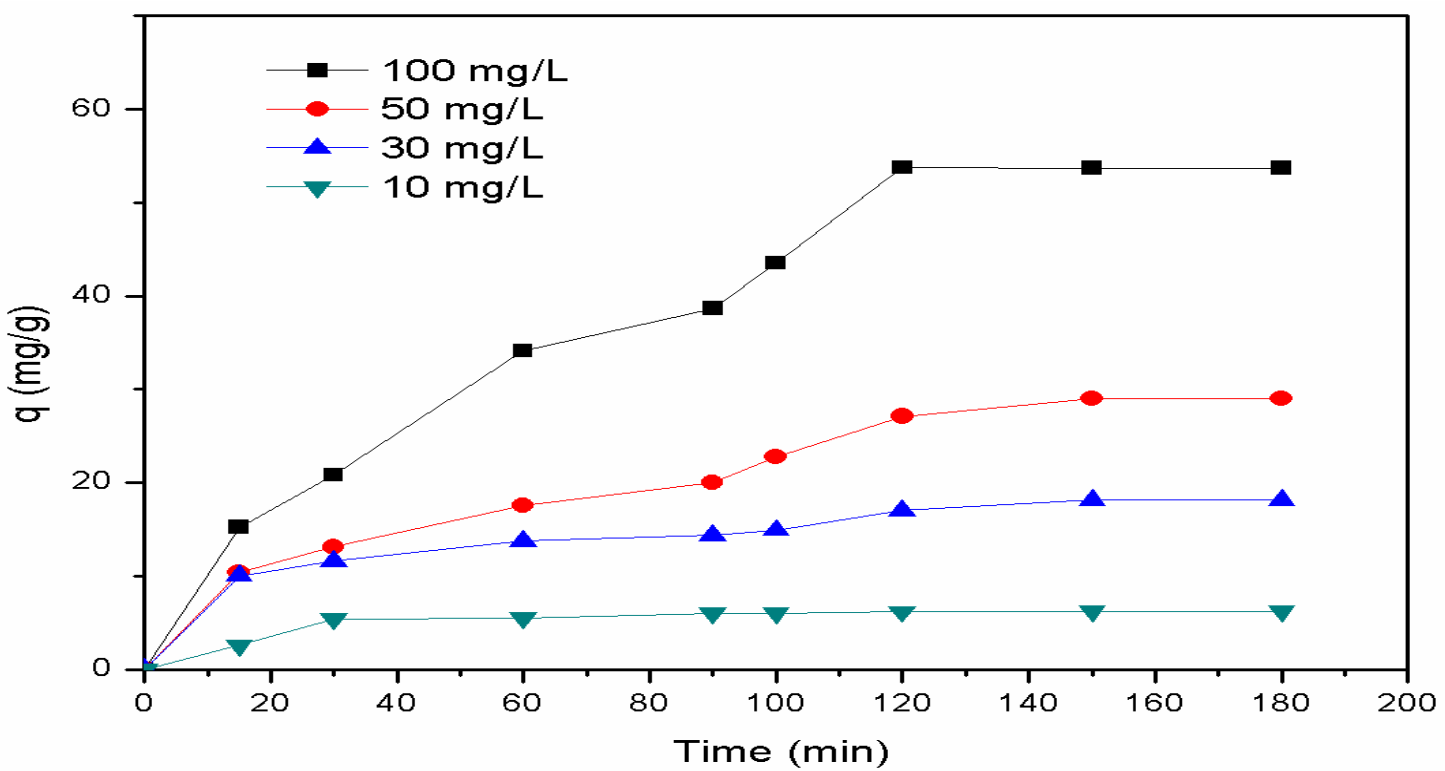

Fig. 4 - Effect of contact time and initial concentration on SDS removal by $\mathrm{Zn}(2) \mathrm{Al} 600$ (adsorbent dose $=1 \mathrm{~g} / \mathrm{L}, \mathrm{pH}=$ neutral, $\mathrm{T}=25^{\circ} \mathrm{C}$, stirring speed $=200 \mathrm{rpm}$ ).

Table 4

Parameters for the adsorption of SDS on $\mathrm{Zn}(2) \mathrm{Al}$ and $\mathrm{Zn}(2) \mathrm{Al} 600$ at different initial concentrations

\begin{tabular}{|c|c|c|c|c|c|c|c|c|}
\hline \multirow{2}{*}{$\begin{array}{c}\text { Adsorbent } \\
\text { Initial } \\
\text { concentration } \\
(\mathrm{mg} / \mathrm{L}) \\
\end{array}$} & \multicolumn{3}{|c|}{ Pseudo first order constant } & \multicolumn{4}{|c|}{ Pseudo second order constant } & \multirow{2}{*}{$\begin{array}{c}\mathrm{q}_{\mathrm{e}, \exp } \\
(\mathrm{mg} / \mathrm{g})\end{array}$} \\
\hline & $\begin{array}{c}\mathrm{K}_{1} \cdot 10^{-2} \\
\left(\mathrm{~min}^{-1}\right)\end{array}$ & $\begin{array}{c}\mathrm{q}_{\mathrm{e}, \mathrm{cal}} \\
(\mathrm{mg} / \mathrm{g})\end{array}$ & $\mathrm{R}^{2}$ & $\begin{array}{c}\mathrm{K}_{2} \cdot 10^{-4} \\
(\mathrm{~g} / \mathrm{mg} \cdot \mathrm{min})\end{array}$ & $\begin{array}{c}\mathrm{q}_{\mathrm{e}, \mathrm{cal}} \\
(\mathrm{mg} / \mathrm{g})\end{array}$ & $\begin{array}{c}\mathrm{h} \\
(\mathrm{mg} / \mathrm{g} \cdot \mathrm{min})\end{array}$ & $\mathrm{R}^{2}$ & \\
\hline $\mathrm{Zn}(2) \mathrm{Al}$ & & & & & & & & \\
\hline 100 & 3.082 & 72.515 & 0.6304 & 0.918 & 106.382 & 1.039 & 0.9953 & 43.675 \\
\hline 50 & 1.953 & 27.267 & 0.9123 & 8.836 & 33.411 & 0.986 & 0.9938 & 24.302 \\
\hline 30 & 1.581 & 13.689 & 0.9207 & 30.477 & 14.170 & 0.611 & 0.9951 & 15.49 \\
\hline 10 & 1.979 & 6.689 & 0.7691 & 41.163 & 4.761 & 0.093 & 0.9953 & 5.89 \\
\hline $\mathrm{Zn}(2) \mathrm{Al} 600$ & & & & & & & & \\
\hline 100 & 1.519 & 51.289 & 0.9757 & 1.871 & 76.511 & 0.842 & 0.9756 & 53.73 \\
\hline 50 & 1.313 & 25.324 & 0.9458 & 4.76 & 37.907 & 1.211 & 0.9627 & 29 \\
\hline 30 & 1.433 & 12.449 & 0.8250 & 19.499 & 20.296 & 0.322 & 0.9767 & 18.169 \\
\hline 10 & 2.8 & 5.865 & 0.8644 & 216.351 & 6.464 & 0.648 & 0.9991 & 6.2 \\
\hline
\end{tabular}

Table 5

Isotherm parameters for SDS adsorption onto $\mathrm{Zn}(2) \mathrm{Al}$ and $\mathrm{Zn}(2) \mathrm{Al} 600$

\begin{tabular}{|c|c|c|c|c|c|c|c|c|c|c|}
\hline \multirow[t]{2}{*}{ Adsorbent } & \multicolumn{3}{|c|}{ Freundlich model } & \multicolumn{4}{|c|}{ Langmuir model } & \multicolumn{3}{|c|}{ Tempkin model } \\
\hline & $\begin{array}{c}\mathrm{K}_{\mathrm{f}} \\
(\mathrm{mg} / \mathrm{g})\end{array}$ & $\mathrm{n}$ & $\mathrm{R}^{2}$ & $\begin{array}{c}\mathrm{K}_{1} \\
(\mathrm{~L} / \mathrm{mg})\end{array}$ & $\begin{array}{c}\mathrm{q}_{\mathrm{m}} \\
(\mathrm{mg} / \mathrm{g})\end{array}$ & $\mathrm{R}^{2}$ & $\mathrm{R}_{\mathrm{L}}$ & $\begin{array}{c}\text { B } \\
(\mathrm{j} / \mathrm{mol})\end{array}$ & $\begin{array}{c}\mathrm{K}_{\mathrm{t}} \\
(\mathrm{L} / \mathrm{g})\end{array}$ & $\mathrm{R}^{2}$ \\
\hline $\mathrm{Zn}(2) \mathrm{Al}$ & 0.8968 & 0.9989 & 0.9087 & 0.0118 & 105.485 & 0.997 & 0.4585 & 13.580 & 0.313 & 0.9497 \\
\hline Zn(2)Al600 & 2.4743 & 1.257 & 0.9397 & 0.0213 & 90.252 & 0.9968 & 0.3189 & 0.318 & 0.526 & 0.9044 \\
\hline
\end{tabular}

The linear plots of the two equilibrium models were showed in Figs. 5 and 6 . The fitted constants for the two models along with regression coefficients $\left(\mathrm{R}^{2}\right)$ are summarized in Table 5 .

The adsorption equilibrium data fit both Freundlich and Langmuir equations with a correlation coefficient value greater than 0.99 for both adsorbents. In our investigation for the two adsorbents, $R_{L}$ was found to be between 0 and 1 indicating a favorable Langmuir adsorption.

\section{Photocatalytic degradation studies}

\section{Effect of initial SDS concentration}

In this study we varied the initial concentration of SDS in the range of $10 \mathrm{mg} / \mathrm{L}-100 \mathrm{mg} / \mathrm{L}$ and the 
other parameters were fixed (adsorbent dose $10 \mathrm{~g} / \mathrm{L}$, $\mathrm{pH}$ neutral and temperature $=25^{\circ} \mathrm{C}$ ). As seen from Fig. 7 the photodegradation efficiency depend inversely on the initial SDS concentration. With initial SDS concentration of $10 \mathrm{mg} / \mathrm{L}$ the photodegradation efficiency was higher. This phenomenon is due to the fact that when the initial SDS concentration increase the formation rate of $\mathrm{OH} \bullet$ radical decrease, which can be explained by the fact that when there are enough SDS molecules the light will be adsorbed by these molecules and the photons never reach the photocatalyst surface. $^{26,27}$

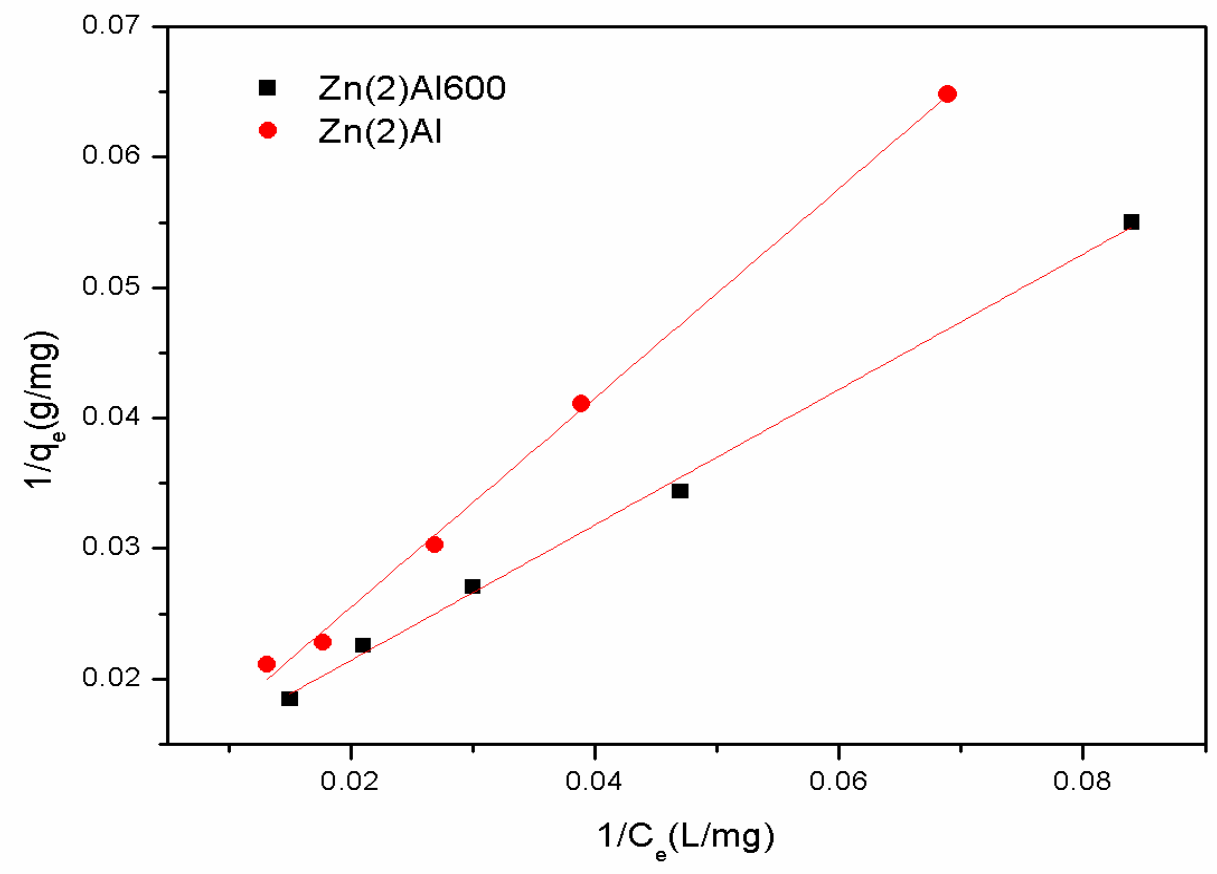

Fig. 5 - Langmuir plots for SDS adsorption on $\mathrm{Zn}(2) \mathrm{Al}$ and $\mathrm{Zn}(2) \mathrm{Al} 600$

$\left(\mathrm{C}_{0}=5-120 \mathrm{mg} / \mathrm{L}\right.$, adsorbent dose $=1 \mathrm{~g} / \mathrm{L}, \mathrm{pH}=$ neutral, $\mathrm{T}=25^{\circ} \mathrm{C}$, contact time $=160 \mathrm{~min}$, stirring speed $\left.=200 \mathrm{rpm}\right)$.

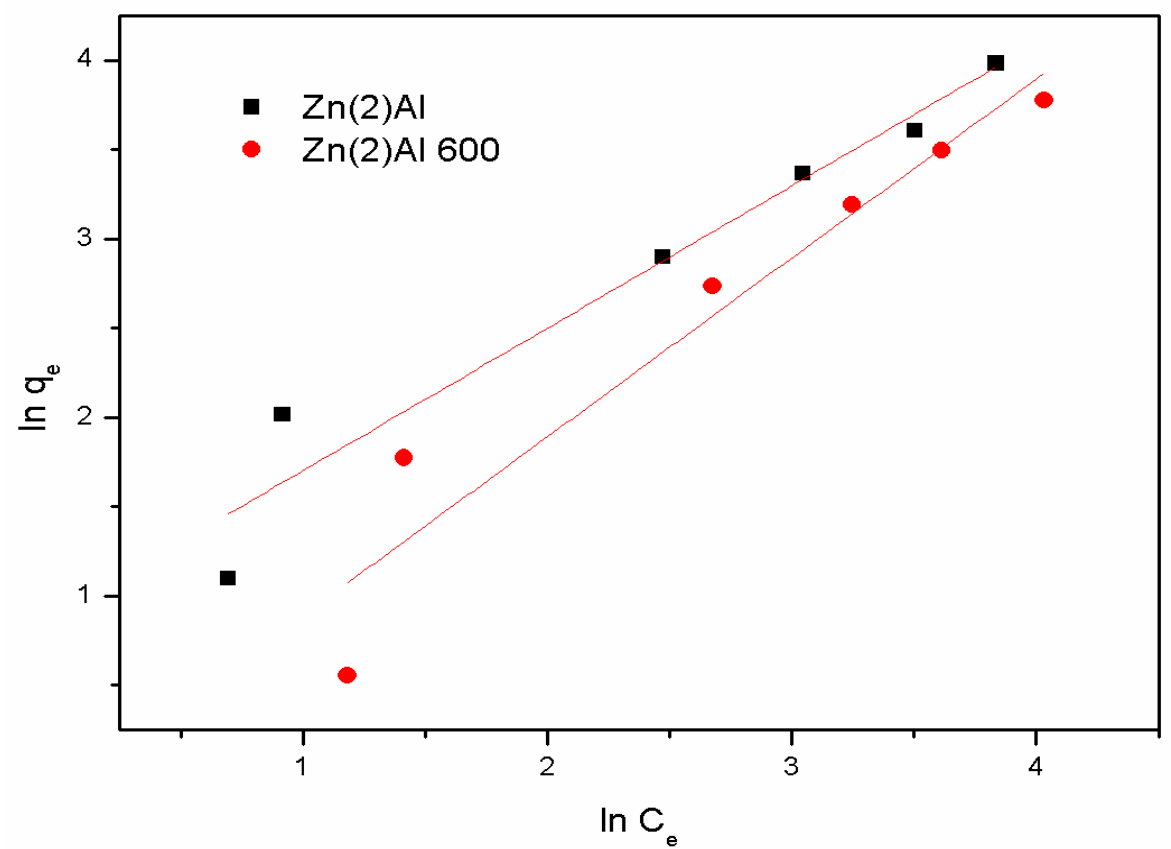

Fig. 6 - Freundlich plots for SDS adsorption on $\mathrm{Zn}(2) \mathrm{Al}$ and $\mathrm{Zn}(2) \mathrm{Al} 600$

$\left(\mathrm{C}_{0}=5-120 \mathrm{mg} / \mathrm{L}\right.$, adsorbent dose $=1 \mathrm{~g} / \mathrm{L}, \mathrm{pH}=$ neutral, $\mathrm{T}=25^{\circ} \mathrm{C}$, contact time $=160 \mathrm{~min}$, stirring speed $\left.=200 \mathrm{rpm}\right)$. 


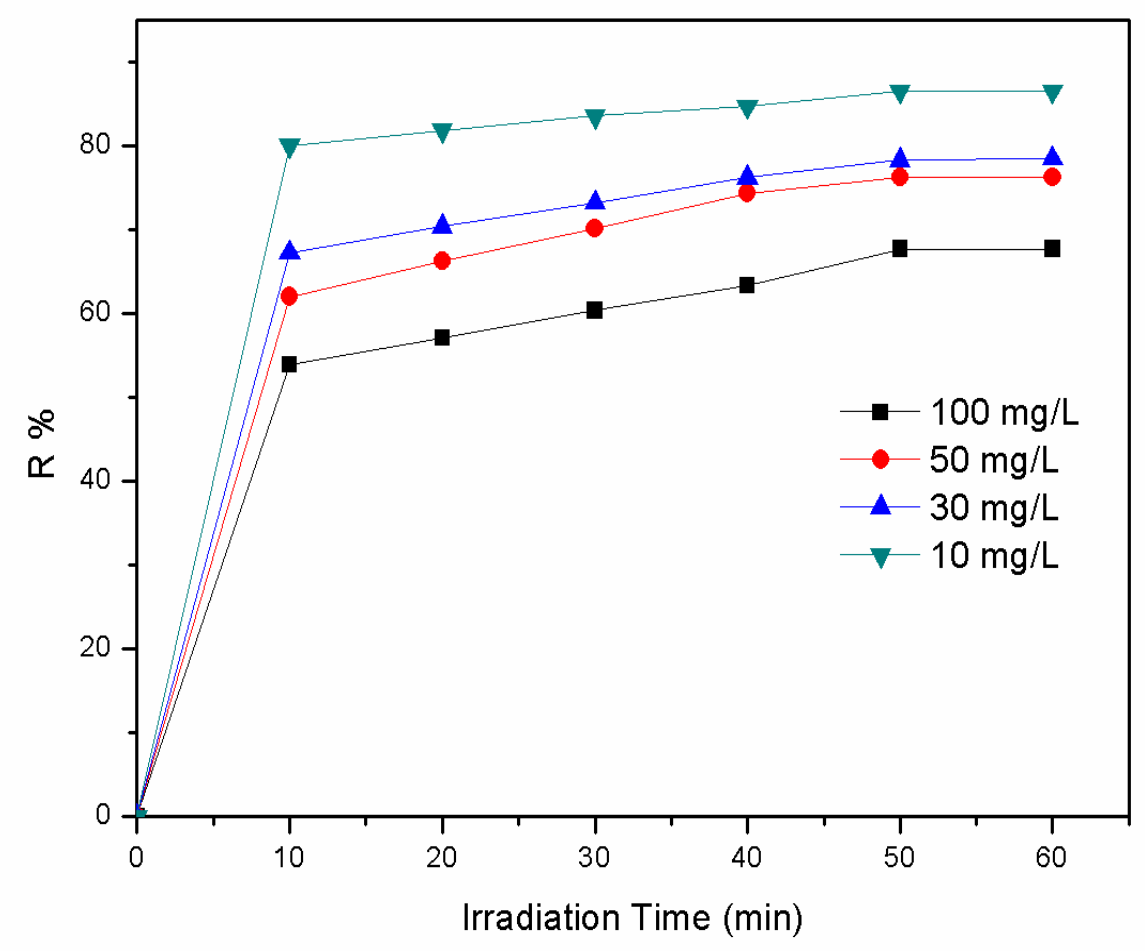

Fig. 7 - Effect of initial SDS concentration on the photodegradation of SDS by $\mathrm{Zn}(2) \mathrm{Al} 600$ (photocatalyst dose $=10 \mathrm{~g} / \mathrm{L}, \mathrm{pH}=$ neutral, $\mathrm{T}=25^{\circ} \mathrm{C}$ ).

\section{Kinetics of SDS photodegradation}

The Langmuir-Hinshelwood model is commonly used to describe the kinetics of photocatalytic reactions of organic compounds in aqueous solutions. It relates the degradation rate $r$ and the concentration of organic compound $C$, and is expressed as follows.

$$
r=-\frac{d c}{d t}=\frac{K_{r} K_{a d} C}{1+K_{a d} C}
$$

where $k_{r}$ is the rate constant and $K_{a d}$ is the adsorption equilibrium constant. When the adsorption is relatively weak and the reactant concentration is low, the equation can be simplified to the first-order kinetics with an apparent rate constant $K_{a p p} \cdot \ln \frac{C_{0}}{C}=K_{a p p} t$ where $C_{0}$ is the initial concentration after achieving adsorption-desorption equilibrium. Plotting $\ln$ $\left(C_{0} / C\right)$ versus irradiation time $(t)$ yields a straight line, and the slope is the apparent rate constant Kapp. The half-life of the degraded organic compound can be calculated by the following equation:

$$
t_{1 / 2}=\frac{0.693}{K_{a p p}}
$$

Fig. 8 presents results of the SDS photodegradation kinetic studies for $\mathrm{Zn}(2) \mathrm{Al}$ and $\mathrm{Zn}(2) \mathrm{Al} 600$ samples, apparent constant $K_{\text {app }}$, SDS half-life, and the linearization coefficient $R^{2}$ are summarized in Table 7. As shown in Table 6, the SDS photodegradation results adjusted well to the pseudo-first-order kinetic model.

Table 6

\begin{tabular}{|c|c|c|c|c|c|c|}
\hline \multirow{2}{*}{$\begin{array}{l}\text { SDS Initial } \\
\text { concentration } \\
(\mathrm{mg} / \mathrm{L})\end{array}$} & \multicolumn{3}{|c|}{$\mathrm{Zn}(2) \mathrm{Al}$} & \multicolumn{3}{|c|}{$\mathrm{Zn}(2) \mathrm{Al} 600$} \\
\hline & $\begin{array}{c}\mathrm{K}_{\text {app }}\left(10^{-2}\right) \\
\left(\mathrm{min}^{-1}\right)\end{array}$ & $\begin{array}{c}\mathrm{t}_{1 / 2} \\
(\mathrm{~min})\end{array}$ & $\mathrm{R}^{2}$ & $\begin{array}{c}\mathrm{K}_{\text {app }}\left(10^{-2}\right) \\
\left(\mathrm{min}^{-1}\right)\end{array}$ & $\begin{array}{c}\mathrm{t}_{1 / 2} \\
(\mathrm{~min})\end{array}$ & $\overline{\mathrm{R}^{2}}$ \\
\hline 100 & 0.65 & 106.615 & 0.9846 & 0.651 & 106.451 & 0.9812 \\
\hline 50 & 0.701 & 98.858 & 0.9629 & 0.975 & 71.076 & 0.986 \\
\hline 30 & 0.831 & 83.393 & 0.9949 & 1.192 & 58.137 & 0.9795 \\
\hline 10 & 0.774 & 89.534 & 0.9695 & 1.093 & 63.403 & 0.9798 \\
\hline
\end{tabular}

The Langmuir-Hinshelwood model parameters of photocatalytic degradation 
a

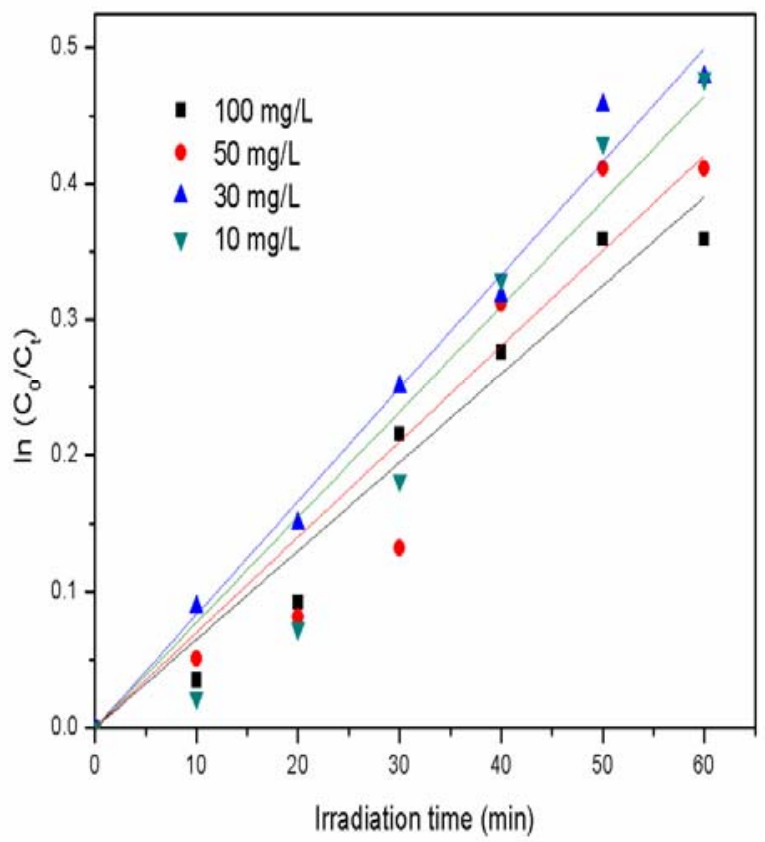

b

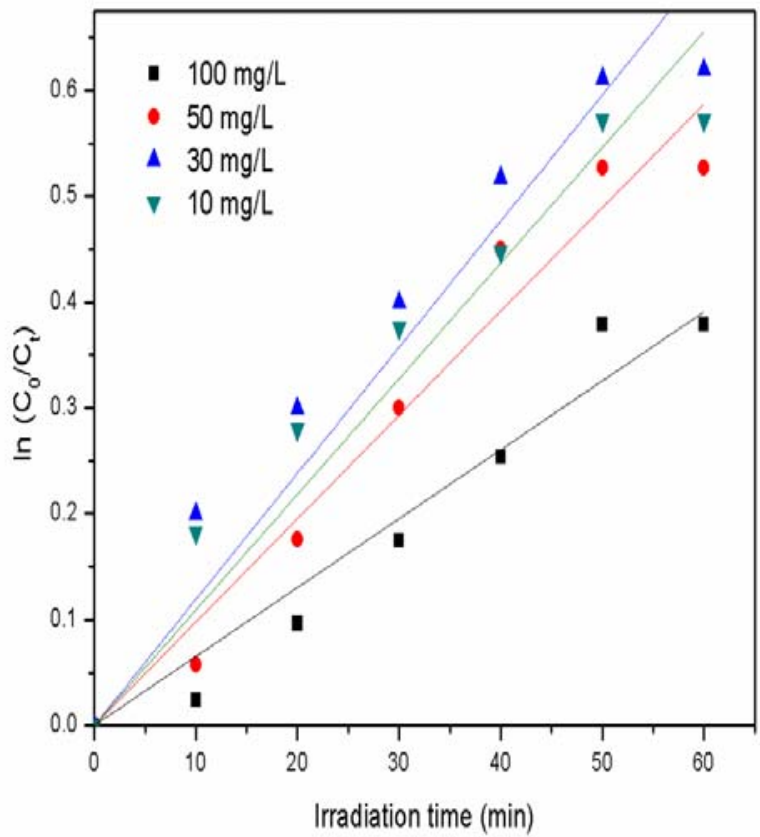

Fig. 8 - Pseudo-first-order kinetics photodegradation of SDS, by Langmuir- Hinshelwood model on Zn(2)Al and (b) $\mathrm{Zn}(2) \mathrm{Al} 600$ (photocatalyst dose $=10 \mathrm{~g} / \mathrm{L}, \mathrm{pH}=$ neutral, $\mathrm{T}=25^{\circ} \mathrm{C}$ ).

\section{CONCLUSION}

The present study shows that both $\mathrm{Zn}(2) \mathrm{Al}$ and $\mathrm{Zn}(2) \mathrm{A} 1600$ prepared by coprecipitation method could be used as an effective adsorbent for the removal of SDS from aqueous solution by adsorption and photocatalyic degradation.

The $\mathrm{Zn}^{2+1} \mathrm{Al}^{3+}$ molar ratio and calcination were found to affect the adsorption and photodegradation process. $\mathrm{Zn}(2) \mathrm{Al} 600$ with $\mathrm{Zn} / \mathrm{Al}$ molar ratio of 2 , calcined at a temperature of $600{ }^{\circ} \mathrm{C}$ was found to be more efficient for SDS removal than that uncalcined $\mathrm{Zn}(2) \mathrm{Al}$. The adsorption process was found to depend on the amount of adsorbent, the initial concentration of the SDS, the contact time and the temperature.

Kinetics of SDS adsorption from aqueous solution followed a pseudo-second-order model. Adsorption isotherms indicated that SDS removal by both $\mathrm{Zn}(2) \mathrm{Al}$ and $\mathrm{Zn}(2) \mathrm{Al} 600$ were an endothermic process and fitted the Langmiur model well. The photocatalytic degradation of follows the first-order kinetics according to the Langmuir-Hinshelwood model.

\section{REFERENCES}

1. E. L. Terechova, G. Zhang, J. Chen, N. A. Sosnina and F. Yang, J. Environ. Chem. Eng., 2014, 2, 2111-2119.
2. A. K. Mungray and P. Kumar, Process Saf. Environ. Prot., 2009, 87, 254- 260.

3. E. Olkowska, M. Ruman and Ż. Polkowska, J. Anal. Methods Chem., 2014, 2, 769-708.

4. G. A. Ciorba, C. Radovan, I. Vlaicu and L. Pitulice, Electrochim. Acta, 2000, 46, 297-303.

5. K. Ikehata and M. G. El-Din, Ozone Sci. Eng., 2004, 26, 327-343.

6. Y. Y. Eng, V. K. Sharma and A. K. Ray, Chemosphere, 2010, 79, 205-209.

7. T. Zhang, T. Oyama, S. Horikoshi, J. Zhao, N. Serpone and H. Hikada, Appl. Catal. B: Environ., 2003, 42, 13-20.

8. S. R. Taffarel and J. Rubio, Miner. Eng., 2010, 237, 71-79.

9. N. Schouten, L.G. van der Ham, G.J. Euverink and A.B. de Haan, Water Res., 2007, 41, 4233-4241.

10. E. Jurado, S. Fernandez, J. Nunez-Olea, G. Luzon and M. Lechuga, Chemosphere, 2006, 65, 278-285.

11. C. Busetto, G. Del Piero, G. Mamara, F. Trifiró and A. Vaccari, J. Catalysis, 1984, 85, 260-266.

12. F. Cavani, F. Trifiro and A. Vaccari, Catal. Today, 1991, 11, 173-301.

13. D. G. Cantrell, L. J. Gillie, A. F. Lee and K. Wilson, Appl. Catal. A Gen., 2005, 287, 183-190.

14. X. Cheng, X. Huang, X. Wang and D. Sun, J. Hazard. Mater., 2010, 177, 516-523.

15. J. T. Kloprogge, D. Wharton, L. Hickey and R. L. Am, Mineral., 2002, 8, 623-629.

16. H. Toshiyuki, Y. Yasumasa, K. Katsunori and T. Atsumu, Clays and Clay Minerals, 1995, 43, 427-432.

17. B. Dudek, P. Kustrowski, A. Białas and P. Natka, Mater. Chem. Phys., 2012, 132, 929-936.

18. W. Dongjin, L. Yongde, X. Shuhu, C. Jing and Z. Jian, Colloids and Surfaces A: Physicochem., 2015, 469, 307-314.

19. M. Tong, H. Chen, Z. Yang and R. Wen, Int. J. Mol. Sci., 2011, 12, 1756-1766. 
20. D. Chaara, I. Pavlovic, F. Bruna, M. A. Ulibarri, K. Draoui and C. Barriga, Appl. Clay Scie., 2010, 50, 292-298.

21. G. Wu, X. Wang, B. Chen, J. Li, N. Zhao, W. Wei and Y. Sun, Appl. Catal. A: Gen., 2007, 329, 106-111.

22. J. Zhou, S. Yang, J. Yu and Z. Shu, J. Hazard. Mater., 2011, 192, 1114-1121.

23. C. L. Zhang, Y. Baojun, Z. Shengnan, W. Bainian and X. Bing, J. Mater. Chem. A, 2014, 2, 10202-10208.
24. Z. Tong, P. Zheng, B. Bai, H. Wang and Y. Suo, Catalysts, 2016, 6, 58-64.

25. A. Akyol, H. C. Yatmaz and M. Bayramoglu, Appl. Catalysis B: Environ., 2004, 54, 19-24.

26. C. Changchun, L. Jiangfeng, L. Ping and Y. Benhai, $A d v$. Chem. Eng. Sci., 2011, 1, 9-14.

27. O. Ozdemir, C. Mustafa, S. Eyup, A. Fatma, S. Mehmet and M. Celik, J. Hazardous Mater., 2007, 147, 625-632. 